\title{
Umbundu Language
}

National Cancer Institute

\section{Source}

National Cancer Institute. Umbundu Language. NCI Thesaurus. Code C154187.

A Niger-Congo Bantu language spoken by the Ovimbundu people of Angola. 